Jurnal Kesmas Asclepius

Volume 2, Nomor 2, Desember 2020

e-ISSN: 2684-8287

p-ISSN: 2656-8926

DOI: https://doi.org/10.31539/jka.v2i2.1630

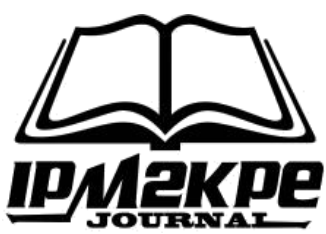

\title{
PEMBERIAN PENDIDIKAN KESEHATAN MELALUI TELENURSING TERHADAP PENINGKATAN PENGETAHUAN DAN PENCEGAHAN KEPUTIHAN PATOLOGIS PADA REMAJA
}

\author{
Yessi Andriani ${ }^{1}$, Maidaliza ${ }^{2}$, Rinona Iverta Alvaensi ${ }^{3}$ \\ Universitas Perintis Indonesia ${ }^{1,2,3}$ \\ yessi.andriani16@gmail.com ${ }^{1}$
}

\begin{abstract}
ABSTRAK
Tujuan penelitian ini untuk mengetahui pengaruh pemberian pendidikan kesehatan melalui telenursing terhadap peningkatan pengetahuan dan pencegahan keputihan patologis pada remaja di SMK Negeri 2 Bukittinggi tahun 2020. Penelitian ini menggunakan metode quasy eksperimen dengan rancangan group pre-post test design. Hasil penelitian didapatkan peningkatan rerata tingkat pengetahuan dan pencegahan keputihan, dimana nilai rerata tingkat pengetahuan sebelum dan setelah diberikan pendidikan kesehatan yaitu 12,77 dan 27,18 sedangkan rerata pencegahan keputihan sebelum dan setelah diberikan pendidikan kesehatan yaitu 18,55 dan 33,82. Hasil uji statistik didapatkan nilai $p$-value 0,000 untuk tingkat pengetahuan dan nilai $p$-value 0,000 untuk pencegahan keputihan patologis. Simpulan, ada pengaruh pemberian pendidikan kesehatan melalui telenursing terhadap peningkatan pengetahuan dan pencegahan keputihan patologis.
\end{abstract}

Kata Kunci: Keputihan, Pendidikan Kesehatan, Telenursing

\section{ABSTRACT}

The purpose of this study was to determine the effect of providing health education through telenursing on increasing knowledge and prevention of pathological vaginal discharge in adolescents at SMK Negeri 2 Bukittinggi in 2020. This study used a quasy experimental method with a group pre-post test design. The results showed an increase in the mean level of knowledge and prevention of leucorrhoea, where the mean level of knowledge before and after health education was 12.77 and 27.18, while the mean prevention of vaginal discharge before and after health education was 18.55 and 33.82. The statistical test results obtained a p-value of 0.000 for the level of knowledge and a pvalue of 0.000 for the prevention of pathological leucorrhoea. In conclusion, there is an effect of providing health education through telenursing on increasing knowledge and preventing pathological vaginal discharge.

Keywords: Leucorrhoea, Health Education, Telenursing

\section{PENDAHULUAN}

Menurut World Health Organization (WHO) remaja jarang dalam memperhatikan kebersihan pada organ genetalia eksternalnya (Abrori et al., 2017). Sehingga dapat menimbulkan masalah pada kesehatan reproduksinya. Keputihan (leukorea atau fluor albus) adalah salah satu masalah kesehatan reproduksi yang sering terjadi. Banyak remaja 
putri yang beranggapan bahwa keputihan merupakan hal yang wajar. Tetapi hal tersebut tidaklah benar, keputihan yang tidak dicegah dengan hygine yang baik akan dapat mengakibatkan terjadinya penyakit infeksi (Nur, 2018).

Keputihan adalah cairan putih yang keluar secara berlebihan dari vagina. keputihan terbagi atas dua yaitu keputiahan normal (fisisologis) dan keputihan abnormal (patologis). Keputihan merupakan gejala yang sering dialami oleh banyak wanita dan merupakan masalah kedua sesudah gangguan haid. Pada umumnya, banyak orang yang menganggap keputihan sebagai hal yang wajar. Pendapat ini tidak sepenuhnya benar, karna ada berbagai sebab yang bisa mengakibatkan keputihan. Kurangnya pengetahuan mengakibatkan keputihan menjadi masalah besar. Padahal keputihan dapat menjadi indikasi dari suatu penyakit (Febryary et al., 2016).

Untuk meningkatan pengetahuan remaja tentang keputihan dapat dilakukan dengan pemberian pendidikan kesehatan. Pendidikan kesehatan adalah suatu proses belajar yang dalam pendidikan itu terjadi proses perubahan ke arah yang lebih baik dari individu, kelompok atau masyarakat (Putri, 2015). Dalam pemberian pendidikan kesehatan banyak metode yang bisa dilakukan, tetapi dengan kondisi pandemik covid-19 saat ini dimana kita harus mematuhi protokol kesehatan maka peneliti memilih untuk memberikan pendidikan kesehatan melalui telenursing. Dimana telenursing merupakan penggunaaan teknologi untuk memberikan asuhan keperawatan dan praktek keperawatan jarak jauh kepada pasien yang bertujuan untuk memperbaiki perawatan kesehatan (Fadhila \& Afriani, 2019).

Dari hasil penelitian Padila et al., (2018) pada 15 orang perawat di RSUD Dr. M. Yunus Bengkulu, didapatkan antusias perawat dalam menerima tantangan baru dalam pemberian pelayanan telenursing sangat tinggi, hal tersebut dapat berdampak pada kemampuan meningkatkan komunikasi yang efektif antara perawat dan pasien. Perawat pun bertambah semangat dalam belajar meningkatkan kapasitas dirinya guna memberikan pelayanan keperawatan yang paripurna.

Sebanyak 75\% wanita di Indonesia pernah mengalami keputihan minimal satu kali dalam hidupnya dan setengah diantaranya mengalami keputihan sebanyak dua kali atau lebih. Hal ini berkaitan dengan cuaca yang lembab yang mempermudah wanita Indonesia mengalami keputihan, dimana cuaca yang lembab dapat mempermudah berkembangnya infeksi jamur (Pratiwi, 2016).

Dari hasil penelitian Mardiana \& Nurlaila (2015) di SMP Suryadarma Bandar Lampung, terhadap 60 remaja putri yang memiliki pengetahuan baik sebanyak 30 siswa $(65,0 \%), 37$ siswa $(61,7 \%)$ masih mengalami keputihan/ flour albus dan sedangkan 34 siswa $(56,7 \%)$ tidak melakukan personal hygine. Dari hasil penelitian tersebut ternyata pengetahuan siswa hanya sebatas tahu, tetapi tidak paham dalam melakukan personal hygine untuk perawatan alat reproduksinya.

\section{METODE PENELITIAN}

Penelitian ini menggunakan metode quasi eksperimen dengan rancangan one group pre-post test design. Alat ukur dalam penelitian ini menggunakan kuesioner. Penelitian ini menggunakan uji paired test, dengan sampel 22 siswi di SMK Negeri 2 Bukittinggi. 


\section{HASIL PENELITIAN}

Tabel. 1

Rerata Tingkat Pengetahuan Remaja Putri tentang Keputihan Sebelum Diberikan Pendidikan Kesehatan Melalui Telenursing

\begin{tabular}{lccccc}
\hline Tingkat Pengetahuan & N & Mean & Max & Min & SD \\
\hline Pre-test & 22 & 12,77 & 17 & 9 & 2,349 \\
\hline
\end{tabular}

Berdasarkan tabel 1 menunjukkan bahwa nilai rerata tingkat pengetahuan responden tentang keputihan sebelum diberikan pendidikan kesehatan melalui telenursing adalah 12,77 dengan standar deviasi 2,349.

Tabel. 2

Rerata Pencegahan Keputihan Remaja Putri Sebelum Diberikan Pendidikan Kesehatan melalui Telenursing

\begin{tabular}{cccccc}
\hline Pencegahan & N & Mean & Max & Min & SD \\
\hline Pre-test & 22 & 27,18 & 32 & 22 & 3,034 \\
\hline
\end{tabular}

Berdasarkan tabel 2 menunjukkan bahwa nilai rerata pencegahan keputihan responden sebelum diberikan pendidikan kesehatan melalui telenursing adalah 27,18 dengan standar deviasi 3,034.

Tabel. 3

Rerata Tingkat Pengetahuan Remaja Putri tentang Keputihan Setelah Diberikan Pendidikan Kesehatan melalui Telenursing

\begin{tabular}{cccccc}
\hline Tingkat Pengetahuan & N & Mean & Max & Min & SD \\
\hline Post-test & 22 & 18,55 & 20 & 16 & 0,912 \\
\hline
\end{tabular}

Berdasarkan tabel 3 menunjukkan bahwa nilai rerata tingkat pengetahuan responden tentang keputihan setelah diberikan pendidikan kesehatan melalui telenursing adalah 18,55 dengan standar deviasi 0,912 .

Tabel. 4

Rerata Pencegahan Keputihan Remaja Putri Setelah Diberikan Pendidikan Kesehatan melalui Telenursing

\begin{tabular}{cccccc}
\hline Pencegahan & N & Mean & Max & Min & SD \\
\hline Post-test & 22 & 33,82 & 37 & 30 & 2,363 \\
\hline
\end{tabular}

Berdasarkan tabel 4 menunjukkan bahwa nilai rerata pencegahan keputihan responden setelah diberikan pendidikan kesehatan melalui telenursing adalah 33,82 dengan standar deviasi 2,363.

Tabel. 5

Rerata Tingkat Pengetahuan Remaja Putri tentang Flour albus Sebelum dan Setelah Diberikan Pendidikan Kesehatan melalui Telenursing

\begin{tabular}{ccccccc}
\hline $\begin{array}{c}\text { Tingkat } \\
\text { Pengetahuan }\end{array}$ & Mean & SD & $95 \%$ CI & SE & P-Value & N \\
\cline { 1 - 5 } Sebelum & 12,77 & 2,349 & $\begin{array}{c}-6,778- \\
4,778\end{array}$ & 0,483 & 0,000 & 22 \\
\hline Sesudah & 18,55 & 0,912 & & \\
\hline
\end{tabular}


Berdasarkan tabel 5 menunjukkan bahwa hasil uji statistik diperoleh $p$-value= 0,000 , adanya pengaruh pemberian pendidikan kesehatan melalui telenursing terhadap peningkatan pengetahuan responden antara sebelum dan sesudah dengan nilai rerata sebelum 12,77 dan nilai rerata sesudah 18,55, dimana terjadi peningkatan pengetahuan responden tentang keputihan yang dapat dilihat dari nilai rerata yang didapatkan.

Tabel. 6

Rerata Pencegahan Keputihan Patologis pada Remaja Sebelum dan Setelah Diberikan Pendidikan Kesehatan melalui Telenursing

\begin{tabular}{ccccccc}
\hline Pencegahan & Mean & SD & $95 \%$ CI & SE & P-Value & N \\
\cline { 1 - 3 } Sebelum & 27,18 & 3,034 & $\begin{array}{c}-8,223- \\
5,049\end{array}$ & \multirow{2}{*}{0,763} & \multirow{2}{*}{0,000} & \multirow{2}{*}{22} \\
\cline { 1 - 4 } Sesudah & 33,82 & 2,363 & & & \\
\hline
\end{tabular}

Berdasarkan tabel 6 menunjukkan bahwa hasil uji statistik diperoleh $p$-value= 0,000 , adanya pengaruh pemberian pendidikan kesehatan melalui telenursing terhadap pencegahan keputihan antara sebelum dan sesudah dengan nilai rerata sebelum 27,18 dan nilai rerata sesudah 33,82 , dimana terjadi peningkatan pencegahan keputihan yang dapat dilihat dari nilai rerata yang didapatkan.

\section{PEMBAHASAN}

Hasil penelitian dinyatakan dari 22 responden sebelum diberikan pendidikan kesehatan melalui telenursing didapatkan nilai rerata tingkat pengetahuan yaitu 12,77 $(\mathrm{SD}=2,349)$ dan nilai rerata pencegahan keputihan patologis yaitu 27,18 $(\mathrm{SD}=3,034)$. Setelah diberikan pendidikan kesehatan melalui telenursing nilai rerata responden mengalami kenaikan dengan nilai rerata tingkat pengetahuan yaitu 18,55 $(\mathrm{SD}=0,912)$ dan nilai rerata pencegahan keputihan patologis yaitu 33,82 ( $\mathrm{SD}=2,363)$. Dari hasil uji statistik didapatkan $p$-value tingkat pengetahuan yaitu 0,000 dan $p$-value pencegahan keputihan patologis yaitu 0,000 , yang berarti ada pengaruh pemberian pendidikan kesehatan melalui telenursing terhadap peningkatan pengetahuan dan pencegahan keputihan patologis pada remaja di SMK Negeri 2 Bukittinggi.

Dapat diasumsikan bahwa pendidikan kesehatan melalui telenursing terlaksanakan dengan baik terhadap responden yang dapat dilihat dari peningkatan nilai rerata tingkat pengetahuan serta pencegahan keputihan sebelum dan setelah diberikan pendidikan kesehatan melalui telenursing.

Penelitian ini didukung oleh penelitian Darmala (2018) yang membahas tentang hubungan pengetahuan dan sikap remaja putri dengan kejadian flour albus yang menyatakan dari 45 responden didapatkan $64,4 \%$ (29 remaja putri) memiliki pengetahuan tinggi tentang flour albus dan untuk angka kejadian flour albus sebanyak 60\% (27 remaja putri) tidak mengalami keputihan. Dari hasil uji statistik chi-square didapatkan nilai $p$ value 0,182 dan nilai $\mathrm{OR}=2,857$, maka dapat diartikan terdapat hubungan yang bermakna antara pengetahuan dengan kejadian flour albus. Penelitian ini juga didukung oleh penelitian Fauziah (2015) tentang pengaruh penyuluhan tentang keputihan terhadap perilaku pencegahan keputihan, dari 54 responden didapatkan sebanyak 50 orang $(92,6 \%)$ yang memiliki perilaku pencegahan baik dari hasil uji statistik didapatkan nilai $p$-value= 0,000 yang berarti terdapat pengaruh penyuluhan kesehatan terhadap pencegahan keputihan. 
Menurut hasil penelitian Sukamto et al., (2018) dari hasil uji statistik terdapat hubungan yang signifikan antara variabel dimana nilai $p$-value pengetahuan 0,004 , nilai p-value sikap 0,041 dan nilai $p$-value perilaku 0,000 , dengan $40,4 \%$ responden memiliki tingkat pengetahuan baik dan $71,6 \%$ tidak pengalami keputihan patologis.

Keputihan (leucorrhea, vaginal discharge) adalah keluarnya sekret atau cairan selain darah yang berlebihan dari liang vagina dengan variasi bau, konsistensi, dan warna (Pradnyandari et al., 2019). Menurut Trisnawati (2018) keputihan (flour albus) terbagi atas 2 jenis yaitu keputihan normal (fisioligis) dan keputihan patologis (abnormal). Keputihan merupakan hal yang normal bagi wanita, tetapi keputihan tidak boleh dianggap remeh karna dapat menimbulkan masalah kesehatan. Adapun beberapa cara yang dapat dilakukan untuk mencegah keputihan yaitu menjaga kebersihan organ kewanitaan, menghindari penggunaan sabun pembersih kewanitaan, hindari penggunaan celana yang ketat, biasakan mengganti pembalut 4-6 jam sekali saat menstruasi (Wulaningtyas \& Widyawati, 2018).

Banyak kejadian keputihan yang disebabkan oleh bakteri kandidosis vulvovagenitis yang dikarenakan banyak wanita yang tidak mengetahui cara merawat kebersihan daerah vaginanya dan penyebab lainnya juga disebabkan oleh vaginitis bacterial dan trichomonas vaginalis. Pencegahan terhadap keputihan yang paling utama adalah menjaga personal hygiene terutama daerah vagina (Johar et al., 2013). Kurangnya pengetahuan remaja tentang keputihan dapat mempengaruhi kebiasaannya dalam memperhatikan kejadian keputihan yang dialaminya (Darmala, 2018).

Pengetahuan merupakan hasil dari tahu dan ini terjadi setelah orang melakukan pengindraan terhadap objek tertentu (Sani, 2011). Adapun faktor-faktor yang dapat mempengaruhi tingkat pengetahuan antara lain informasi, budaya dan pengalaman (Febriyanto, 2016). Pengetahuan sangat erat hubungannya dengan pendidikan, sehingga diharapkan dengan pendidikan yang tinggi maka semakin luas juga pengetahuannya. Tetapi bukan berarti seseorang yang berpendidikan rendah dapat dikatakan rendah pula pengetahuannya, karna peningkatan pengetahuan tidak hanya didapatkan dari pendidikan formal saja tetapi juga dapat diperoleh dari pendidikan nonformal (Irnawati, 2016).

Banyak metode dalam memberikan pendidikan kesehatan, dalam penelitian ini yang dikarenakan situasi pandemik covid-19 maka peneliti memilih memberikan pendidikan kesehatan melalui telenursing. Sejalan dengan penelitian Padila et al., (2018), menyatakan home visit telenursing ini sangat bermanfaat dan berguna dalam layanan akses kesehatan guna menurunkan angka hospitalisasi yang tidak terencana dan mengurangi stress keluarga. Telenursing merupakan penggunaaan teknologi untuk memberikan asuhan keperawatan dan praktek keperawatan jarak jauh kepada pasien yang bertujuan untuk memperbaiki perawatan kesehatan (Fadhila \& Afriani, 2019). Sedangkan pendidikan kesehatan adalah suatu proses belajar yang dalam pendidikan itu terjadi proses perubahan kearah yang lebih baik dari individu, kelompok atau masyarakat (Putri, 2015).

\section{SIMPULAN}

Ada pengaruh yang signifikan antara pemberian pendidikan kesehatan melalui telenursing terhadap peningkatan pengetahuan dan ada pengaruh yang signifikan antara pemberian pendidikan melalui telenursing terhadap pencegahan keputihan patologis pada remaja di SMK Negeri 2 Bukittingi tahun 2020. 


\section{SARAN}

Diharapkan kepada pihak sekolah agar dapat memberikan pendidikan kesehatan berkaitan dengan keputihan sehingga dapat meningkatkan kesehatan remaja. Untuk peneliti selanjutnya hasil peneilitian ini hendaknya dapat digunakan sebagai acuan bagi peneliti dalam mengembangkan penelitian sejenisnya, peneliti selanjutnya bisa melakukan penelitian tentang pemberian pendidikan kesehatan melalui telenursing dengan media telenursing yang lainnya.

\section{DAFTAR PUSTAKA}

Abrori, A. \& Hernawan, A. D., \& Ermulyadi, E. (2017). Faktor yang Berhubungan Dengan Kejadian Keputihan Patologis Siswi SMAN 1 Simpang Hilir Kabupaten Kayong Utara. Unnes Journal of Public Health, 6(1), 24. DOI: 10.15294/ujph.v6i1.14107

Darmala, E. (2018). Hubungan Pengetahuan dan Sikap Remaja Putri dengan Kejadian Flour Albous pada Remaja Putri di SMP Negeri 4 Kuranci Kecamatan Guguak Tahun 2018. Journal of Linguistics, 3(2), 139-157. https://doi.org/10.18041/23823240/saber.2010v5n1.2536

Fadhila, R., \& Afriani, T. (2019). Penerapan Telenursing dalam Pelayanan Kesehatan: Literature Review. Jurnal Keperawatan Abdurrab, 3(2), 77-84. DOI: https://doi.org/10.36341/jka.v3i2.837

Fauziah, N. (2015). Pengaruh Penyuluhan tentang Keputihan terhadap Perilaku Pencegahan Keputihan pada Siswi Kelas X di SMA Negeri I Pundong Bantul Yogyakarta. Biomass Chem Eng, 49(23-6), 23-34. http://www.ti.com/lit/ds/symlink/cc2538.html

Febriyanto, M. A. B. (2016). Hubungan antara Pengetahuan dan Sikap dengan Perilaku Konsumsi Jajanan Sehat di MI Sulaimaniyah Mojoagung Jombang Tahun 2016. Jurnal Keperawatan Muhammadiyah, 1(2), 7-17. http://repository.unair.ac.id/46023

Febryary, D. R., Astuti, S., \& Hartinah, H. (2016). Gambaran Pengetahuan, Sikap dan Perilaku Remaja Putri dalam Penanganan Keputihan di Desa Cilayung. Jurnal Sistem Kesehatan, 2(1), 40-46. DOI: https://doi.org/10.24198/jsk.v2i1.10418

Irnawati, Y. (2016). Perbedaan Tingkat Pengetahuan Perawatan Keputihan Pra Training dan Post Training pada Siswi SMP Negeri 2 Jaken Kabupaten Pati. Ilmu Kebidanan Dan Kesehatan, 7, 73-80. https://docplayer.info/amp/29905109

Johar, W. E., Rejeki, S., \& Khayati, N. (2013). Persepsi dan Upaya Pencegahan Keputihan pada Remaja Putri di SMA Muhammadiyah 1 Semarang. JKMat (Jurnal Keperawatan Maternitas), 1, 37-45. diakses dari https://jurnal.unimus.ac.id/index.php/JKMat/article/view/931

Mardiana, Z., \& Nurlaila, N. (2015). Hubungan Pengetahuan dan Personal Hygiene dengan Kejadian Keputihan (Flour Albus) pada Remaja Putri. Jurnal Keperawatan, 11(1), 15-20. https://ejurnal.poltekkes-tjk.ac.id/index.php/JKEP/article/view/378

Nur, H. A. (2018). Hubungan Persepsi, Sikap, dan Perilaku Remaja Putri tentang Personal Hygiene Genitalia dengan Kejadian Fluor Albus (Keputihan). Jurnal Profesi Keperawatan, 5(1), 1-13. http://jurnal.akperkridahusada.ac.id/index.php/jpk/article

Pradnyandari, I. A. C., Surya, I. G. N. H. W., \& Aryana, M. B. D. (2019). Gambaran Pengetahuan, Sikap, dan Perilaku tentang Vaginal Hygiene terhadap Kejadian Keputihan Patologis pada Siswi Kelas 1 di SMA Negeri 1 Denpasar periode Juli 2018. Intisari Sains Medis, 10(1), 88-94. DOI: 10.15562/ism.v10i1.357 
Padila, P., Lina, L., Febriawati, H., Agustina, B., \& Yanuarti, R. (2018). Home Visit Berbasis Sistem Informasi Manajemen Telenursing. Jurnal Keperawatan Silampari, 2(1), 217-235. https://doi.org/https://doi.org/10.31539/jks.v2i1.305

Pratiwi, T. M., Sabiu, Y., \& Fachlevy, A. F. (2016). Hubungan Pengetahuan, Stres, Penggunaan Antiseptik dan Penggunaan Pembalut dengan Kejadian Fluor Albus pada Remaja Siswi Sma Negeri 8 Kendari Tahun 2017. JIMKESMAS: Jurnal Ilmiah Mahasiswa Kesehatan Masyarakat, 2(6), 1-8. https://media.neliti.com/media/publications/198330-none.pdf

Putri, J. (2015). Pengaruh Pendidikan Kesehatan (Tutor Sebaya) terhadap Perilaku Kebersihan Organ Reproduksi Remaja Putri di SMA Negeri 1 Kecamatan Palembayan Tahun 2015. Skripsi, 13(3), 1576-1580. http://repo.stikesperintis.ac.id/498

Sani, F. N. (2011). Hubungan Tingkat Pengetahuan Sehat - Sakit dengan Sikap Mahasiswa Universitas Muhammadiyah Surakarta tentang Perilaku Hidup Bersih dan Sehat. KesMaDasKa 2(2), 12-18. diakses dari https://www.jurnal.stikeskusumahusada.ac.id/index.php/JK/article/view/3

Sukamto, N. R., Yahya, Y. F., Handayani, D., Argentina, F., \& Liberty, I. A. (2018). Hubungan Pengetahuan, Sikap, dan Perilaku Perawatan Vagina terhadap Kejadian Keputihan Patologis pada Mahasiswi Program Studi Pendidikan Dokter Fakultas Kedokteran Universitas Sriwijaya. Majalah Kedokteran Sriwijaya, 50(4), 213-221. https://ejournal.unsri.ac.id/index.php/mks/article/view/8571

Trisnawati, I. (2018). Faktor-Faktor yang Berhubungan dengan Keputihan Patologis pada Wanita Usia Subur yang Bekerja di PT Unilever Cikarang Bejas. Jurnal Penelitian Kesehatan Suara Forikes, 9(1), 45-50. https://forikesejournal.com/index.php/SF/article/view/79

Wulaningtyas, E. S., \& Widyawati, E. (2018). Kecemasan terhadap Infeksi Maternal pada Wus (Relationship Between Albus Flour Events and Anxiety Levels Maternal infection at wus). Jurnal Ners dan Kebidanan, 5(2), 123-128. https://doi.org/10.26699/jnk.v5i2.ART.p123 